\title{
Blood uric acid in executives
}

\author{
W. H. PHOON and G. PINCHERLE \\ Industrial Health Unit, Ministry of Labour, Singapore, and BUPA Medical Centre Ltd, \\ 210 Pentonville Road, King's Cross, London N1 9TA
}

\begin{abstract}
Phoon, W. H., and Pincherle, G. (1972). Brit. J. industr. Med., 29, 334-337. Blood uric acid in executives. The mean blood uric acid in over 7000 male executives was found to be $5.96 \mathrm{mg} /$ $100 \mathrm{ml}$ (standard deviation 1.12). This was significantly higher than the mean level $(4.64 \mathrm{mg} /$ $100 \mathrm{ml}$ ) in 778 females from the same social background. The women showed a rise in mean level with age which was not found in the men. In the men, significant correlations were found with haemoglobin level, cholesterol level, electrocardiographic findings, relative weight, and stated alcohol consumption. These results and the importance of blood uric acid determinations in a screening programme are discussed.
\end{abstract}

Various studies have been made into the relationship between blood uric acid (BUA) levels and a number of other factors. Correlations have been found with body weight (Montoye et al., 1967), haemoglobin levels (Acheson and O'Brien, 1966), social class (Acheson, 1969), alcohol consumption (Evans, Prior, and Harvey, 1968), serum cholesterol (Salvini and Verdi, 1959; Brooks and Mueller, 1966), and coronary artery disease (Kolbel, Gregorova, and Sonka, 1967). However, some of the above associations were not found by all these authors.

This paper presents the results obtained in a large group of British businessmen in an attempt to elucidate the interplay of the various factors causing hyperuricaemia and the various results that may ensue.

\section{Population and methods}

The population studied was a group of executives who had attended comprehensive routine medical examinations over the last seven years (from 1964 to 1970) at the Institute of Directors Medical Centre in London. All of those studied were apparently well at the time of examination, persons known to have gout having been excluded.

The population thus comprised about 7400 male business executives. This number varied slightly with the different factors studied because, unfortunately, not all the laboratory investigations were done on every executive at the time of the examination, the main reasons being either that the tests had been inadvertently overlooked or that the blood had been taken but had clotted before the test could be carried out. However, the variation in the size of the population studied was small, of the order of 1 to $2 \%$. A much smaller population of 778 women was also studied. These were mainly wives of business executives, with a few who were executives in their own right.

A more extensive description of the screening programme and some of the results obtained have been published previously (Pincherle and Shanks, 1967a and b; Wright, 1967; Richardson and Pincherle, 1969 and 1971; Gillespie, 1970; Pincherle, 1971).

The uric acid determinations were carried out using the standard phosphotungstate reduction Technicon autoanalyser method.

\section{Results}

The distribution of BUA levels was approximately normal (Table 1). Women had a lower mean uric acid level $(4.64 \mathrm{mg} / 100 \mathrm{ml})$ than men $(5.96 \mathrm{mg} /$ $100 \mathrm{ml})$. This difference was statistically significant $(t=34.6 ; \quad \mathrm{P}<0.0001)$. The Figure shows that there was no change in mean BUA with age in men, but a marked menopausal rise in women. Older women (45 or over) had a significantly higher BUA $(4.86 \mathrm{mg} / 100 \mathrm{ml})$ than the younger ones $(4.39 \mathrm{mg} /$ $100 \mathrm{ml})(t=6.7 ; \mathrm{P}<0.0001)$. The relationship between other factors and mean BUA has not been 
TABLE 1

Distribution OF $\begin{aligned} & \text { Uric ACID LeVels in } 7464 \\ & \text { BusinesSMen }\end{aligned}$

\begin{tabular}{c|r|r}
\hline Uric acid $(m g \%)$ & No. & $\%$ \\
\hline$<3 \cdot 5$ & 76 & 1 \\
$3 \cdot 5-3 \cdot 7$ & 67 & 1 \\
$3 \cdot 8-4 \cdot 1$ & 127 & 2 \\
$4 \cdot 2-4 \cdot 4$ & 240 & 3 \\
$4 \cdot 5-4 \cdot 7$ & 371 & 5 \\
$4 \cdot 8-5 \cdot 0$ & 567 & 8 \\
$5 \cdot 1-5 \cdot 3$ & 690 & 9 \\
$5 \cdot 4-5 \cdot 6$ & 885 & 12 \\
$5 \cdot 7-5 \cdot 9$ & 963 & 13 \\
$6 \cdot 0-6 \cdot 2$ & 766 & 10 \\
$6 \cdot 3-6 \cdot 5$ & 644 & 9 \\
$6 \cdot 6-6 \cdot 8$ & 520 & 7 \\
$6 \cdot 9-7 \cdot 1$ & 497 & 7 \\
$7 \cdot 2-7 \cdot 4$ & 347 & 5 \\
$7 \cdot 5-7 \cdot 7$ & 247 & 3 \\
$7 \cdot 8-8 \cdot 0$ & 182 & 2 \\
$8 \cdot 1-8 \cdot 3$ & 107 & 1 \\
$8 \cdot 4-8 \cdot 6$ & 60 & 1 \\
$8 \cdot 7+$ & 108 & 1 \\
\hline
\end{tabular}

considered further for women because of the relatively small numbers involved in some of the subgroups.

There is considerable controversy over what constitutes the best measure of obesity (Richardson and Pincherle, 1969). We have considered relative weight $\left(100 \times\right.$ observed weight $\div$ expected weight $\left.^{1}\right)$. Table 2 shows that mean BUA increases with relative weight. This was statistically significant; correlation coefficient $\mathrm{r}=0.29, \mathrm{P}<0.001$.

There is a steady rise in mean BUA with increasing haemoglobin levels (Table 3 ). The correlation coefficient $(r=0.076)$ is statistically significant $(P<$ 0.001).

Alcohol consumption is assessed by the examining doctor by questioning the patients. They are then divided into four arbitrary classes: teetotallers, who drink no alcohol at all; light drinkers, who have two or less drinks a day; moderate drinkers, taking three to six drinks a day; and heavy drinkers who indulge in more than six drinks per day. A drink is defined as half a pint of beer or cider, a single gin, whisky or brandy, a wine glass full of wine, or a sherry glass full of sherry or vermouth. This represents approximately $10-20 \mathrm{ml}$ of pure alcohol. Ignoring the teetotallers, who are a small and highly selected group as they include a considerable number who have stopped drinking on medical advice, there is a

${ }^{1}$ Expected weight is calculated for the patient's age and height from the tables of the Metropolitan Life Insurance Co. of New York.

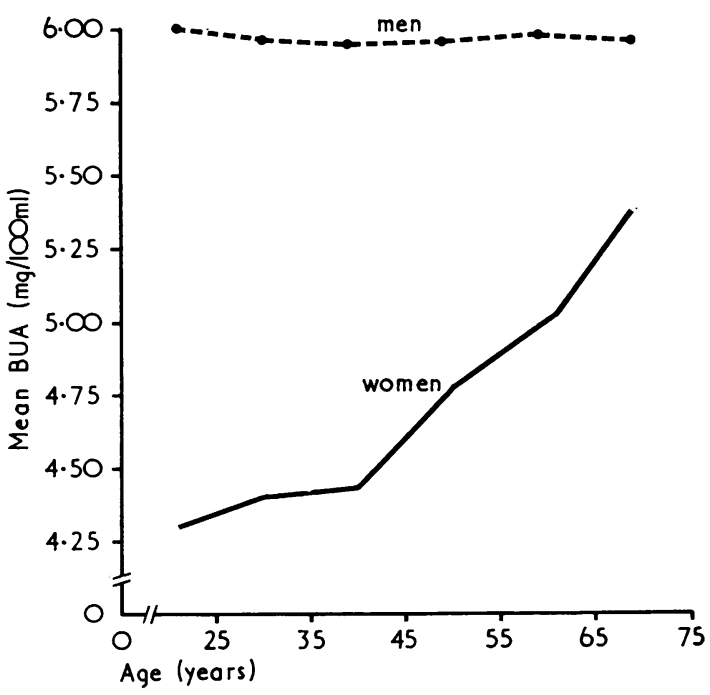

FIGURE. Mean BUA levels in relation to age in men and women.

TABLE 2

Mean bua and Relative Weight ${ }^{1}$ in Male EXECUTIVES

\begin{tabular}{l|ccccccc|c}
\hline & \multicolumn{6}{|c|}{ Relative weight, \% } & \\
\cline { 2 - 6 } & $<80$ & $80-$ & $90-$ & $100-$ & $110-$ & $120-$ & $130+$ & Total \\
\hline $\begin{array}{c}\text { No. } \\
\begin{array}{c}\text { Mean BUA } \\
\text { (mg \%) }\end{array}\end{array}$ & 5.16 & 5.39 & 5.72 & 6.01 & 6.27 & 6.46 & 6.66 & 5.96 \\
$\begin{array}{c}\text { Standard } \\
\text { deviation }\end{array}$ & 1.24 & 0.96 & 1.03 & 1.07 & 1.13 & 1.12 & 1.32 & 1.21 \\
\hline
\end{tabular}

${ }^{1}$ For definition of relative weight see text.

TABLE 3

Mean Uric acid at Different Haemoglobin LeVels in 7332 Male Executives

\begin{tabular}{l|cccccc}
\hline & \multicolumn{5}{|c}{ Haemoglobin $\%(100 \%=14.6 \mathrm{~g} \%)$} \\
\cline { 2 - 7 } & $<80$ & $80-89$ & $90-99$ & $100-109$ & $110-119$ & $120+$ \\
\hline $\begin{array}{l}\text { No. } \\
\begin{array}{c}\text { Mean uric acid } \\
\text { (mg \%) }\end{array}\end{array}$ & 26 & 129 & 2184 & 3954 & 914 & 125 \\
$\begin{array}{c}\text { Standard } \\
\text { deviation }\end{array}$ & 5.45 & 5.61 & 5.86 & 6.00 & 6.09 & 6.17 \\
\hline
\end{tabular}


significant increase in mean BUA with increasing alcohol consumption (Table 4).

Table 5 shows the relationship between cholesterol levels and mean BUA. This is statistically significant $(\mathrm{r}=0.078 ; \mathrm{P}<0.001)$.

All electrocardiograms are reported on by the same cardiologist. On the basis of his reports they have been classified as normal, showing minor abnormalities (e.g., left or right axis deviation, extrasystoles, minor ST-T wave changes) or major abnormalities (e.g., bundle-branch block, left ventricular hypertrophy, $Q$ waves, atrial fibrillation, heart block, severe ST-T wave changes). Both the abnormal groups had significantly higher mean BUA levels (Table 6) than the normals, the major abnormality group having the highest values.

\section{Discussion}

The sex difference in mean BUA levels is well documented (Acheson and O'Brien, 1966; Montoye et al., 1967). The same authors have also described the menopausal rise in women, and this has been con-

TABLE 4

Mean BUA and Alcohol Consumption in 7481 Male Executives

\begin{tabular}{l|c|c|c|c}
\hline & \multicolumn{4}{|c}{ Alcohol consumption } \\
\cline { 2 - 5 } & $\begin{array}{c}\text { Teetotaler } \\
(1)\end{array}$ & $\begin{array}{c}\text { Light } \\
\text { drinker } \\
(2)\end{array}$ & $\begin{array}{c}\text { Moderate } \\
\text { drinker } \\
(3)\end{array}$ & $\begin{array}{c}\text { Heavy } \\
\text { drinker } \\
(4)\end{array}$ \\
\hline No. & 193 & 3913 & 2953 & 422 \\
$\begin{array}{c}\text { Mean BUA } \\
\text { (mg\%) }\end{array}$ & 5.928 & 5.824 & 6.085 & 6.426 \\
$\begin{array}{c}\text { Standard } \\
\text { deviation }\end{array}$ & 1.28 & 1.06 & 1.13 & 1.31 \\
\hline
\end{tabular}

Between groups 2 and $3 t=9.83(\mathrm{P}<0.001)$

Between groups 2 and $4 t=11.09(\mathrm{P}<0.001)$

Between groups 3 and $4 t=5.67(\mathrm{P}<0.001)$

TABLE 5

Mean BUA and Cholesterol Levels in 7453 MALE EXecutives

\begin{tabular}{c|c|c|c}
\hline $\begin{array}{c}\text { Cholesterol } \\
(\text { mg \%) }\end{array}$ & No. & $\begin{array}{c}\text { Mean BUA } \\
(\text { mg \%) }\end{array}$ & $\begin{array}{c}\text { Standard } \\
\text { deviation }\end{array}$ \\
\hline$<210$ & 1244 & $5 \cdot 85$ & $1 \cdot 12$ \\
$210-239$ & 1814 & 5.92 & $1 \cdot 11$ \\
$240-269$ & 1987 & 5.93 & $1 \cdot 09$ \\
$270-299$ & 1383 & 6.04 & $1 \cdot 11$ \\
$300-329$ & 677 & $6 \cdot 11$ & $1 \cdot 14$ \\
$330+$ & 348 & $6 \cdot 24$ & $1 \cdot 29$ \\
\hline
\end{tabular}

TABLE 6

Mean BUA and ECG Findings in 7481 Male EXECUTIVES

\begin{tabular}{l|c|c|c}
\hline & \multicolumn{3}{|c}{ ECG grouping } \\
\cline { 2 - 4 } & $\begin{array}{c}\text { Normal } \\
(1)\end{array}$ & $\begin{array}{c}\text { Minor } \\
\text { changes } \\
(2)\end{array}$ & $\begin{array}{c}\text { Major } \\
\text { changes } \\
(3)\end{array}$ \\
\hline No. & 5384 & 1644 & 453 \\
Mean BUA (mg \%) & 5.93 & 6.00 & 6.22 \\
Standard deviation & 1.11 & 1.13 & 1.22 \\
\hline
\end{tabular}

Between groups 1 and $2 t=2.02(\mathrm{P}<0.05)$

Between groups 1 and $3 t=4.90(\mathrm{P}<0.001)$

Between groups 2 and $3 t=3.71(\mathrm{P}<0.001)$

${ }^{1}$ For explanation see text.

firmed in a separate sample of a social class I population seen at the BUPA Medical Centre.

Acheson and O'Brien (1966) have suggested that the menopausal rise in BUA might be related to a similar rise in haemoglobin. In our population, while the older women had a higher mean haemoglobin $(90.3 \%)$ than the younger ones $(89.4 \%)$ this difference was not statistically significant, unlike the difference in mean BUA levels which was significant. This suggests that changes in haemoglobin levels are unlikely to be the major factor in accounting for the menopausal rise in mean BUA. Evans and his colleagues (1968) did not find an association between haemoglobin and uric acid.

There is general agreement that mean BUA increases with adiposity (Evans et al., 1968; Montoye et al., 1967). This may represent an effect of diet which could also account for the correlation between BUA and haemoglobin and BUA and cholesterol. Both these correlations are so small $(r<0.08)$ that their practical significance, as opposed to the statistical significance, is small. Indeed, Montoye and his colleagues (1967) did not find a significant correlation with cholesterol.

Many of the factors we have considered are affected by age, but as mean BUA in males is not age dependent this cannot account for the various differences we have found.

The relationship between alcohol intake and mean BUA has been reported previously (Evans $e t$ al., 1968; Hall, 1965). This fits in with the traditional picture of the gouty heavy drinker. However, most alcoholic beverages, including port, have a negligible purine content (Documenta Geigy, 1962). If the alcohol itself is to be incriminated rather than some generalized overindulgence some more complex metabolic pathway must be invoked.

Coronary thrombosis and allied degenerative vascular conditions are the major cause of death in 
most western countries. Raised cholesterol levels and ECG abnormalities are associated with an increased statistical risk of developing a coronary thrombosis (Kannel, Dawber, and McNamara, 1966). Breckenridge (1966) found that the incidence of coronary heart disease and hypercholesterolaemia was significantly higher in those with raised BUA levels than in those with normal BUA. Gertler, Levine, Garn, and Levine (1951) also found an association between raised BUA and ischaemic heart disease, and Hall (1965) found a higher incidence of coronary heart disease in patients with gouty arthritis. An association between mean BUA and cholesterol level has also been reported by Brooks and Mueller (1966) though this finding was not present in the series of Montoye et al. (1967).

In view of these various interrelationships it is difficult to say whether a raised BUA level is a true coronary risk factor or merely an associated finding because of its relationship with other factors. As the risk associated with a raised BUA seems to be less than that associated with a raised cholesterol the likelihood is that BUA is not an important risk factor. More detailed studies will be needed to obtain a definite answer.

We should stress that these findings are applicable to this population of executives who are not a random sample of businessmen and it may not be justified to extrapolate from them. Comparisons with other reported mean values are difficult because of differences in laboratory methods. Nevertheless our mean BUA levels for men are much higher than those of most other reported series. This could well represent a true social class difference.

There is considerable controversy over the value of screening examinations in general and which tests should be included. The estimation of BUA is simple, accurate, and cheap, particularly if carried out as part of a large biochemical profile. It is of diagnostic value in patients who have arthritis or who may develop it in the future; it could also be a pointer to chronic leukaemia or of relevance in some cases of renal stone. It is of interest in epidemiological research and, perhaps in the future, it may be shown to be important in relation to degenerative vascular disease. At present there is little evidence that it is worth treating symptomless unexplained hyperuricaemia except perhaps by avoiding dietary excess, or as part of a controlled trial.

This is a condensation of the Dissertation submitted by W. H. Phoon to the University of London for the degree of M.Sc. in Occupational Medicine (1971).
Thanks are due to Dr. H. B. Wright, Director of the Institute of Directors Medical Centre, for permission to use information from records collected at the Centre; and to Miss J. Walford of the London School of Hygiene and Tropical Medicine for valuable statistical advice.

\section{References}

Acheson, R. M. (1969). Social class gradients and serum uric acid in males and femaies. Brit. med. J., 4, 65-67.

and O'Brien, W. M. (1966). Dependence of serum-uric acid on haemoglobin and other factors in the general population. Lancet, 2, 777-778.

Breckenridge, A. (1966). Hypertension and hyperuricaemia. Lancet, 1, 15-18.

Brooks, G. W., and Mueller, E. (1966). Serum urate concentrations amiong university professors: relation to drive, achievement, and leadership. J. Amer. med. Ass., 195, 451-418.

Documenta Geigy (1962). Scientific Tables (6th ed.), edited by K. Diem. Geigy Pharmaceutical Co. Ltd., Manchester.

Evans, J. G., Prior, I. A. M., and Harvey, H. P. B. (1968). Relation of serum uric acid to body bulk, haemoglobin, alcohol intake, in 2 South Pacific Polynesian populations. Ann. rheum. Dis., 27, 319-325.

Gertler, M. M., Levine, S. A., Garn, S. M., and Levine, S. A. (1951). Serum uric acid in relation to age and physique in health and in coronary heart disease. Ann. intern. Med., 34, 1421-1431.

Gillespie, H. W. (1970). Routine abdomina! radiology in periodic health examinations. Acta radiol. (Diagn.), 10, 299-304.

Hall, A. P. (1965). Correlations among hyperuricemia, hypercholesterolemia, coronary disease and hypertension. (Proceedings on Conference on gout and purine metabolism.) Arthr. and Rheum., 8, 846-852.

Kannel, W. B., Dawber, T. R., and McNamara, Patricia, M. (1966). Detection of the coronary prone adult: The Framingham Study. J. Iowa St. med. Soc., 56, 26-34.

Kolbel, F., Gregorova, I., and Sonka, J. (1967). Hyperuricaemia and ischaemic heart disease. Coret. vasa (Praha), 9, 112-118.

Montoye, H. J., Faulkner, J. A., Dodge, H. J., Mikkelsen, W. M., Willis, P. W., and Block, W. D. (1967). Serum uric acid concentration among business executives. Ann. intern. Med., 66, 838-850.

Pincherle, G. (1971). Factors affecting the mean serum cholesterol. J. chron. Dis., 24, 289-297.

- and Shanks, J. (1967a). Haemoglobin values in business executives. Brit. J. prev. soc. Med., 21, 40-42.

— and - (1967b). Value of the erythrocyte sedimentation rate as a screening test. Brit. J. prev. soc. Med., 21, 133-136.

Richardson, J. F., and Pincherle, G. (1969). Heights and weights of British business men. Brit. J. prev. soc. Med., 23, 267-270.

and - (1971). Skinfold measurements of obesity in British businessmen. J. Biosoc. Sci., 3, 13-21.

Salvini, L., and Verdi, G. (1959). Statistical study on correlation between blood level of cholesterol, beta-alpha lipoprotein ratio and uric acid of normal and arteriosclerotic subjects. Gerontologia (Basel), 3, 327-334.

Wright, H. B. (1967). Examining the individual in relation to his environment. J. occup. Med., 9, 397-406.

Received for publication December 15, 1971. 